\title{
ANOMALOUS NEEDLE NUMBERS ON DWARF SHOOTS OF PINUS MUGO AND P. UNCINATA (PINACEAE)
}

\author{
KRYSTYNA BORATYŃSKA ${ }^{1}$, ADAM BORATYŃSKI \\ Polish Academy of Sciences, Institute of Dendrology \\ Parkowa 5, 62-035 Kornik, Poland \\ 1 e-mail: borkrys@man.poznan.pl
}

(Received: September 16, 2002. Accepted: March 10, 2003)

\begin{abstract}
The frequency of occurrence of abnormal, three- (or more) needle dwarf shoots of most southern and central European two-needle pine (Pinus) species were studied. No specimens with more than two-needle dwarf shoots were found in a population of $P$. nigra Arnold subsp. salzmannii (Dunal) Franco from the Iberian Peninsula and in two populations of $P$. uliginosa Neumann from the Sudeten Mountains in Central Europe. Single specimens were found within one population of $P$. pinaster Aiton from the Iberian Peninsula and among six populations of $P$. sylvestris L. from the Iberian Peninsula and Central Europe. Abnormal dwarf shoots mostly with three, but also four, five or six needles were found among 24 of 25 surveyed populations of $P$. mugo Turra and $P$. uncinata Ramond. The average frequency of specimens with at least one three-needle dwarf shoot was $24 \%$ for $P$. mugo and $20 \%$ for $P$. uncinata. The frequencies of occurrence varied significantly among studied populations and were highest in samples collected from the upper elevational range limits of the species in the mountains and near the northern limits of their ranges. The frequency of abnormal dwarf shoots in the same populations was significantly high in 2-3 consecutive years. Needles from three-needle dwarf shoots were not significantly shorter than those of two-needle shoots.
\end{abstract}

KEY WORDS: Pinus mugo, Pinus uncinata, Central and Southern Europe, morphological variation, abnormal dwarf shoots, brachyblasts.

\section{INTRODUCTION}

Pinus mugo Turra and $P$. uncinata Ramond are closely related species, treated recently as subspecies of $P$. mugo sensu lato (= P. mugo complex, see Christensen 1987a). Both taxa and other pines belonging to subsection Sylvestres (Pinus sylvestris L. and P. uliginosa Neumann in Central Europe) normally have two needles per dwarf shoot. For this taxa abnormal dwarf shoots with more than two needles have been found rarely and are regarded as an exception. Among them, three-needle dwarf shoots have been reported most frequently. Such shoots have been described for several localities of Pinus mugo and P. uncinata (Schneider 1913; Penzig 1922; Györffy 1932; Debazac 1962; Jähring 1962; Skawiński 1975; Klaus and Zetter 1978; Boratyński et al. 2000).

The occurrence of specimens of the Pinus mugo complex (P. mugo, P. uncinata and intermediate taxa) with three-needle dwarf shoots has recently been reviewed by Christensen (1987b). On the basis of herbarium materials, he concluded that three-needle dwarf shoots may be found throughout the natural range of the species, but mainly at the upper limit of their altitudinal range. He found 27 spe- cimens with abnormal number of needles among 249 examined herbarium sheets.

The occurrence of three-needle dwarf shoots on Pinus sylvestris is also known from the literature (Penzig 1922; Rettich 1932; Przybylski 1970). Abnormal dwarf shoots in $P$. sylvestris may form as a result of mechanical injury to individual trees (mostly seedlings) (Szymański 1958; Król 1983/1984). The formation of dwarf shoots with three or more needles on $P$. sylvestris was also observed after experimental removal of buds from seedlings (Giertych 1968).

The presence of more than two needles on the dwarf shoots of a two-needle pine species is considered an ancestral state of the trait (Klaus and Zetter 1978).

The main goal of this study was to analyze on random samples the geographical variation of the frequency of occurrence individuals with three-needle dwarf shoots among populations of Pinus mugo and $P$. uncinata throughout their natural range in the mountains of Central and Southern Europe. The abnormal dwarf shoots were reported from these two species and from other pines, but nobody has compared frequencies among the species. For this reason the aim of the study was also the comparison of three-needle dwarf shoots frequencies among $P$. mиgo, $P$. 


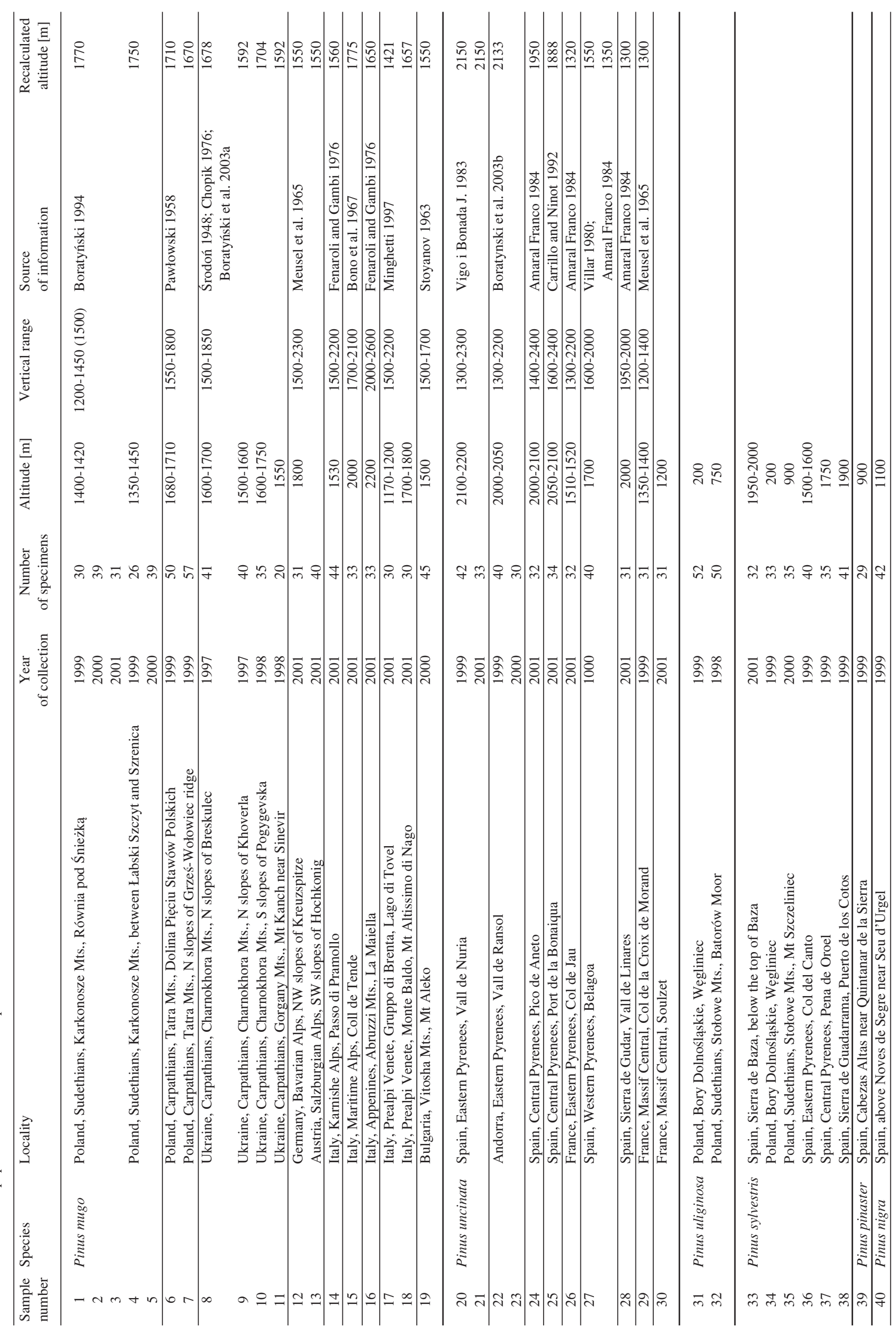


uncinata, $P$. sylvestris, $P$. uliginosa, $P$. nigra and $P$. pinaster coming from the mountains, mostly from the areas close to $P$. mugo and $P$. uliginosa range.

\section{MATERIAL AND METHODS}

Plant material was collected in native populations of $P i$ nus mugo, $P$. uncinata, $P$. uliginosa and $P$. sylvestris, in 1997-2001. All four pine species belong to the Section P $i$ nus subsection Sylvestres and are common in Europe (Little and Critchfield 1969; Boratyński 1993). Single populations of Pinus nigra and $P$. pinaster from the Iberian Peninsula were analyzed as comparative material.

The samples were gathered from individuals without visible symptoms of injury and exclusively from cone-bearing branches. The shoots of the prostrate Pinus mugo were sampled from specimens in distance no less than 30 meters from each other to avoid the possibility of collecting multiple samples from the same individual. In each analyzed population, the two-year-old long shoots were collected from 26-57 individuals (38 on average), always on the sunny, south-facing (SE and SW) side of the crown. Ten two-year-old dwarf shoots were removed from the mid length of the long shoots, and absence or presence of atypical, mostly three-needle, but also four- to six-needle dwarf shoots was reported for each individual separately.

For the individuals with abnormal dwarf shoots, the frequency of dwarf shoot occurrence was calculated as ratio of numbers of abnormal to normal + abnormal dwarf shoots and was presented in $\%$.
The populations were characterized by:

- number of individuals with at least one abnormal dwarf shoot,

- frequency of abnormal dwarf shoots in the sample, calculated as ratio of abnormal to normal + abnormal dwarf shoots.

In total, 1454 individuals were sampled from all taxa (Table 1). The distribution of samples of Pinus mugo and Pinus uncinata covered the geographic ranges of these species (Fig. 1). Four samples of $P$. sylvestris came from the south-western limit of its range, while two others, as well as two samples of $P$. uliginosa, were collected in the and near the northern limit of the Sudeten Mts. (Fig. 1).

The length of needles from typical and atypical dwarf shoots was measured on 25 specimens in two populations of Pinus mugo and on 51 specimens in five populations of $P$. uncinata on fresh material, directly after sampling. Then central portion of the needles (about $2-3 \mathrm{~cm}$ long) were cut out and preserved in $70 \%$ alcohol for further anatomical studies.

One of the Pinus uncinata populations was sampled in each of two years (Table 1, samples 20 and 21). Similarly one population of $P$. mugo was studied in two and another in three consecutive years (Table 1, samples 1-5). Each year random samples of shoots were collected from different or the same individual, depending on the presence of cones.

Dependence of occurrence of specimens bearing abnormal dwarf shoots and frequency of abnormal dwarf shoots in sampled populations with their latitude, altitude and position in vertical range were tested using Pearson's correlation coefficient.

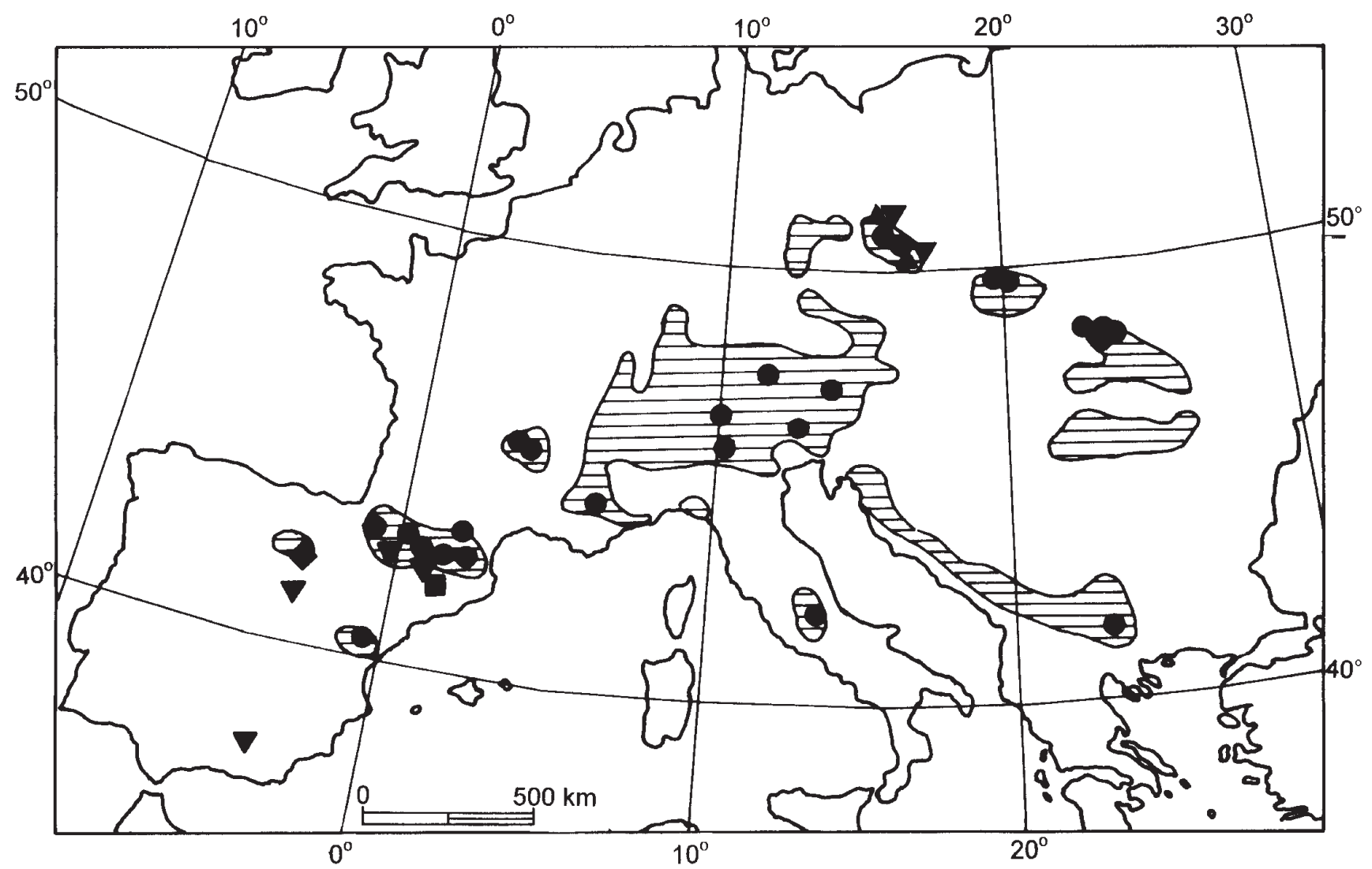

Fig. 1. Distribution of sampled populations against the background of the range of Pinus mugo complex: uliginosa; $\boldsymbol{\nabla}$-Pinus sylvestris; $\mathbf{\square}$-Pinus nigra; $\bullet$ - Pinus pinaster. 
Altitudinal range of the species is different in particular mountain ranges (see Table 1). For this reason statistical comparison among the sampled populations of $P$. mugo are done on altitudes recalculated relative to altitudes at the Tatra Mts. (Table 1, samples 1-19), and among $P$. uncinata to altitudes at the Vall de Nuria in the East Pyrenees (Table 1, samples 20-30). Recalculations were done according to the formula:

$$
\mathrm{ALT}_{\text {xrec } \mathrm{T}}=\mathrm{ALT}_{\mathrm{T} \min }+\frac{\mathrm{ALT}_{\mathrm{x}}-\mathrm{ALT}_{\mathrm{xmin}}}{\mathrm{ALT}_{\mathrm{xmax}}-\mathrm{ALT}_{\mathrm{xmin}}} *\left(\mathrm{ALT}_{\mathrm{T} \max }-\mathrm{ALT}_{\mathrm{Tmin}}\right)
$$

$\mathrm{ALT}_{\mathrm{xrecT}}$ - Altitude of population $\mathrm{x}$ after recalculation $\mathrm{ALT}_{\mathrm{x}}-$ Real altitude of population $\mathrm{x}$

ALT $_{\text {xmin }}$ - Minimal altitude of $P$. mugo (or $P$. uncinata) range in the mountain where sample $\mathrm{x}$ were collected

$\mathrm{ALT}_{\mathrm{xmax}}$ - maximum altitude of P. mugo (or P. uncina-

$t a$ ) in the mountain range where sample $\mathrm{x}$ was collected

$\mathrm{ALT}_{\mathrm{Tmin}}$ - Minimal altitude of $P$. mugo range in the Tatra Mts. (or P. uncinata in the Vall de Nuria)

$\mathrm{ALT}_{\mathrm{Tmax}}$ - Maximal altitude of $P$. mugo range in the Tatra Mts. (or P. uncinata in the Vall de Nuria)

The interaction of frequency of abnormal dwarf shoots within particular populations depends also on their position in altitudinal local range. This includes all environmental influences. For this reason all sampled populations were also analyzed in respect to their position in:

- low (low 25\%),

- central (central 50\%),

- top part of altitudinal range (upper 25\%).

The correlations were analyzed with average recalculated altitudes (see formula 1) of all samples of particular portion of altitudinal species ranges (Table 1).

The lengths of two- and three-needle dwarf shoots were compared using Student's t-test for unpaired data (Underwood 1997; Zar 1999). Calculations and comparisons were made using STATISTICA 5.1.

\section{RESULTS}

\section{Frequencies of abnormal dwarf shoots among taxa}

Dwarf shoots with more than two needles are found on Pinus mugo, $P$. uncinata, $P$. sylvestris and $P$. pinaster (Table 2). The samples of $P$. uliginosa and $P$. nigra do not contain specimens with more than two-needle dwarf shoots.

Only one three-needle dwarf shoot is found on one sample of Pinus sylvestris in the Sierra de Baza, at the southern limit of the range of this species. For $P$. pinaster only one threeneedle dwarf shoot is found (Table 2). Occurrence of more than two-needled dwarf shoots on Pinus sylvestris is very rare, when compared with frequency of occurrence of atypical dwarf shoots on P. mugo and P. uncinata. For this reason more detailed analyses are possible for last species only.

\section{Abnormal dwarf shoots among populations of Pinus mugo}

Geographic differentiation

Pinus mugo has the greatest number of individuals with atypical dwarf shoots. More than $10 \%$ of the specimens examined have more than $10 \%$ three-needle dwarf shoots and nine specimens have more than $50 \%$ of dwarf shoots with three needles. Two specimens from the Sudeten (Karkonosze Mts., samples 1 and 4) have single five-needle dwarf shoots.

Among the analyzed samples of Pinus mugo only one from the Vitosha Mts. in Bulgaria do not contain abnormal dwarf shoots (Table 3). Most of the samples contain 8-15\% specimens with at least one three-needle dwarf shoot, although two populations are characterized with frequency of $50 \%$ or more (Fig. 2).

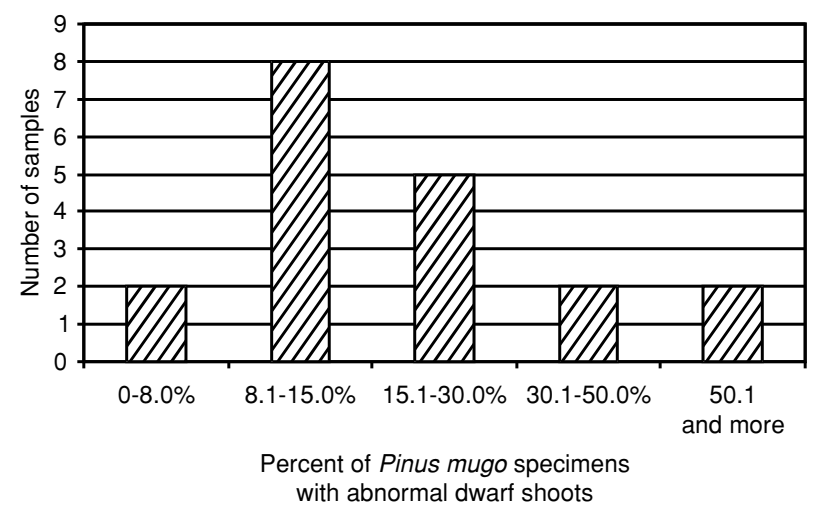

Fig. 2. Numbers of Pinus mugo samples in classes of percentage of individuals with three-needle dwarf shoots.

A geographical analysis of the phenomenon shows that populations from the Tatra Mts. (West Carpathians) and Karkonosze Mts. (Sudeten Mts.) have the highest frequency of specimens with three-needle dwarf shoots. Only one population from the Maritime Alps has a comparatively high frequency of specimens with abnormal dwarf shoots. All other populations located south of the Sudeten Mts. and West. Carpathians have a considerably lower frequency of such specimens (Table 3). Nevertheless, the frequency of specimens with abnormal dwarf shoots in particular popu-

\begin{tabular}{|c|c|c|c|c|c|c|c|c|c|}
\hline \multirow[t]{2}{*}{ Species } & \multirow{2}{*}{$\begin{array}{l}\text { Total number } \\
\text { of specimens } \\
\text { examined }\end{array}$} & \multicolumn{6}{|c|}{ Percentage of specimens with various $\%$ of 3 -needle dwarf shoots } & \multirow{2}{*}{$\begin{array}{c}\text { Percentage of } \\
\text { specimens with } \\
\text { 3-needle dwarf } \\
\text { shoots [\% } \% \text { ] }\end{array}$} & \multirow{2}{*}{$\begin{array}{c}\text { Specimens with } \\
\text { more than 3-needle } \\
\text { dwarf shoots [\%\%] }\end{array}$} \\
\hline & & To $10 \%$ & $11-20 \%$ & $21-30 \%$ & $31-40 \%$ & $41-50 \%$ & $\begin{array}{c}51 \% \\
\text { and more }\end{array}$ & & \\
\hline Pinus mugo & 694 & 13.7 & 4.2 & 1.7 & 1.9 & 1.3 & 1.3 & 24.1 & 0.3 \\
\hline Pinus uncinata & 376 & 8.5 & 3.2 & 2.1 & 0.8 & 1.6 & 4.3 & 20.2 & 1.3 \\
\hline Pinus uliginosa & 102 & & & & & & & 0.0 & 0.0 \\
\hline Pinus sylvestris & 213 & 0.5 & & & & & & 0.5 & 0.0 \\
\hline Pinus nigra & 42 & & & & & & & 0.0 & 0.0 \\
\hline Pinus pinaster & 29 & 3.4 & & & & & & 3.4 & 0.0 \\
\hline
\end{tabular}

TABLE 2. Percentage of abnormal dwarf shoots witnin Pinus mugo, P. uncinata, $P$. uliginosa, $P$. sylvestris, $P$. nigra and $P$. pinaster. 


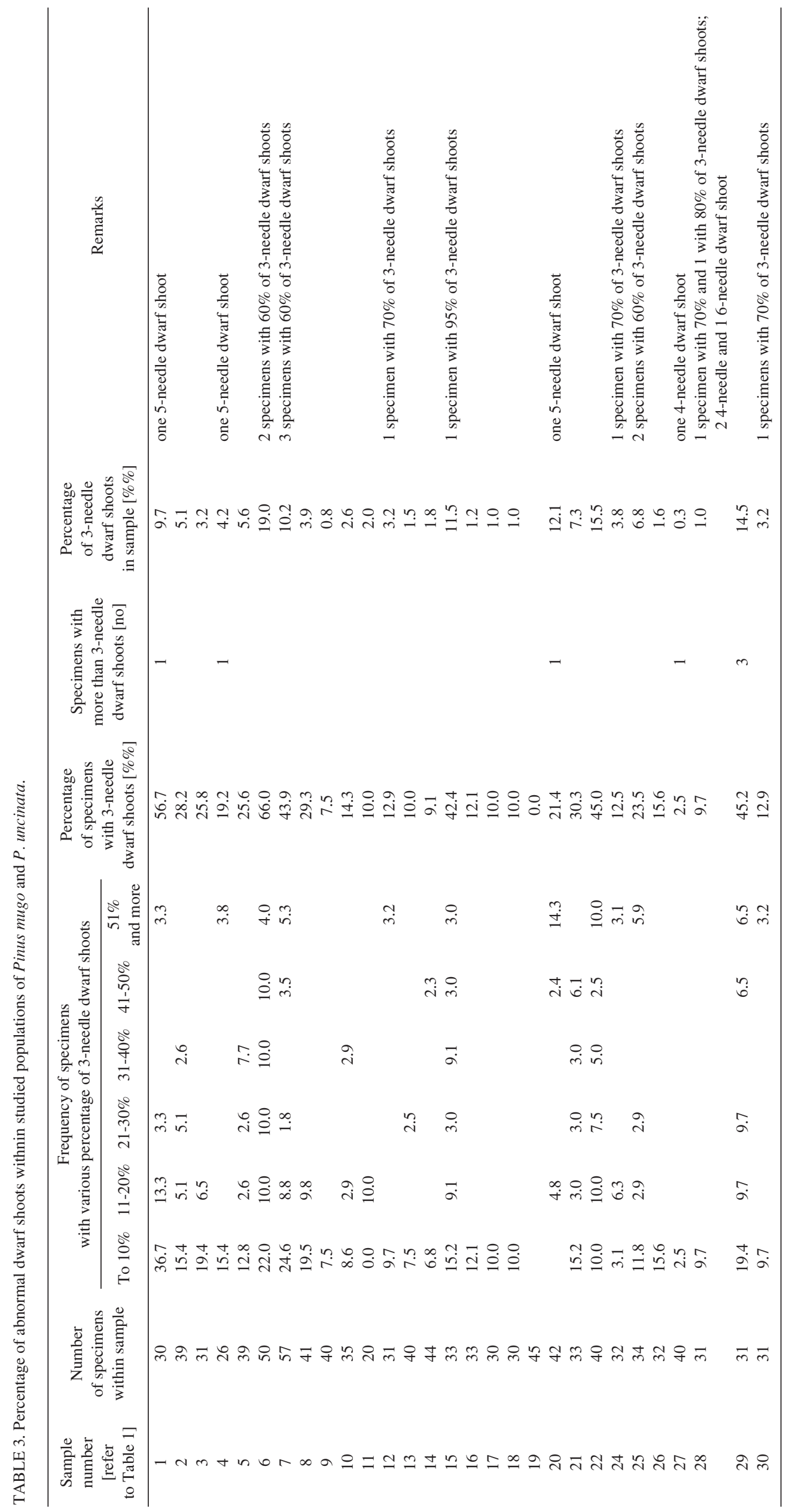


lations is not strongly correlated with latitude of origin (Pearson's $r=0.4371$ ).

The frequency of abnormal dwarf shoots in populations in relation to all dwarf shoots varied even more strongly among the populations, but the ranking of the populations is unchanged (Table 3). The correlation of the frequency of abnormal dwarf shoots in populations with latitude of origin is weak $(r=0.381)$.

\section{Influence of altitude}

The highest frequencies of three-needle dwarf shoots and frequencies of specimens with three-needle dwarf shoots among Pinus mugo populations are found in the samples from the top portion of altitudinal ranges of the species (Fig. 3). The frequency of specimens with abnormal dwarf shoots and frequency of abnormal dwarf shoots are both positively, strongly statistically significantly correlated with position in the altitudinal range of the species (Pearson's $r=0.9923$ and $r=0.9744$ respectively). They are also positively but weak correlated with recalculated altitu$\operatorname{des}(r=0.5855$ and $r=0.5010)$.

The percentage of individuals with abnormal dwarf shoots and the frequency of abnormal dwarf shoots among studied samples of $P$. mugo exhibit rather non-linear, polynomial relationship with altitude (Figs 4A and B). The correlations appear to be slightly more significant at higher elevations.

\section{Variation in time}

Two populations of Pinus mugo from the Karkonosze Mts. were examined for 2 and 3 years (see Table 1). The frequency of specimens with three-needle dwarf shoots in samples collected in the same populations varied from year to year, but was relatively high each year in comparison to the other sampled populations of the species (Table 3, samples 1-3 and 4-5).

\section{Abnormal dwarf shoots among populations}

of Pinus uncinata

Geographic differentiation

The frequency of trees with at least one three-needle dwarf shoot exceeded $20 \%$ among the 376 specimens of $P i$ -

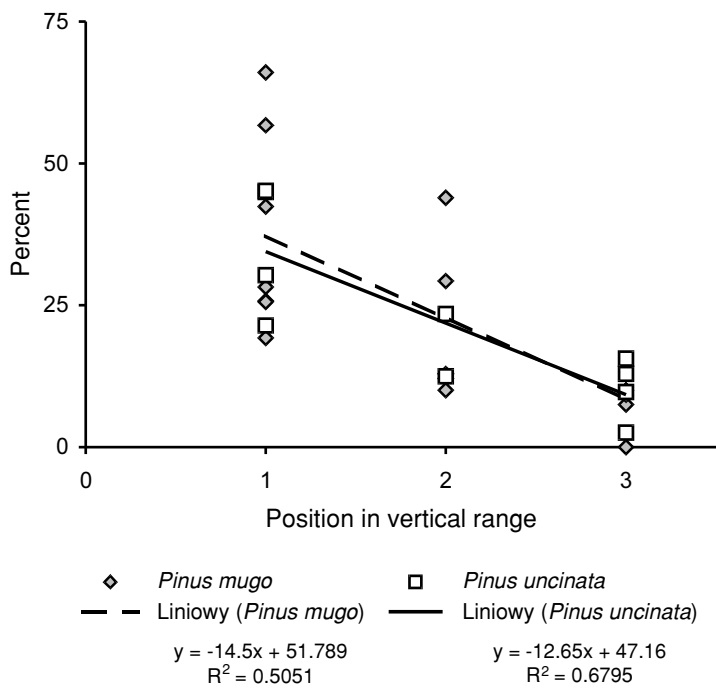

Fig. 3. Frequency of specimens with three-needle dwarf shoots of Pinus mugo and P. uncinata from the upper (1), central (2) and lower (3) parts of the altitudinal range of the species.
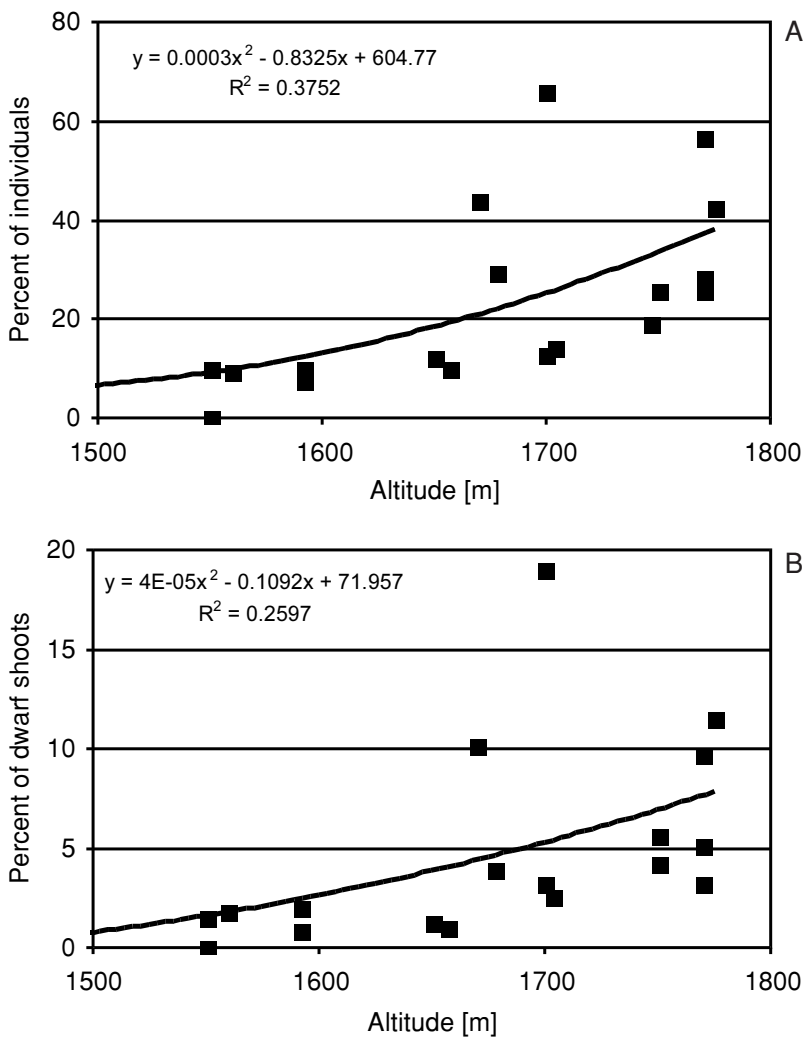

Fig. 4. Relationships of the frequency of Pinus mugo individuals with three-needle dwarf shoots (A) and three needle dwarf shoot (B) in particular populations and its altitudinal origin.

nus uncinata. The frequency of trees exhibiting more than $50 \%$ abnormally developed dwarf shoots per specimen are greater in this taxon than in P. mugo (Table 2). Consequently, the probability of finding of three-needle dwarf shoots on $P$. uncinata is greater than $P$. mugo (Table 2).

Samples of all the analyzed populations of Pinus uncinata contain at least a few specimens with an atypical number of needles on dwarf shoots. The lowest frequency of such trees is found in Belagoa in the West Pyrenees and Vall de Linares in the Sierra de Gudar (Table 3). The highest frequencies of trees with abnormal dwarf shoots are found in the Central Massif and in the East Pyrenees, with a maximum at $45 \%$ in Coll de Croix de Morand in France and in Vall de Ransol in Andorra (Table 3). The highest frequencies of three-needle dwarf shoots in the samples are recorded at the northern limit of the range of this species, as in the case of $P$. mugo. The southernmost and westernmost populations were characterized by a significantly lower number of specimens with abnormally developed dwarf shoots. Neither the frequency of specimens with abnormal dwarf shoots nor the presence of abnormal dwarf shoots among samples correlate strongly with latitude (Pearson's $r=0.2789$ and $r=0.2987$, respectively).

\section{Influence of altitude}

The populations of Pinus uncinata from the upper limit of the species have greater numbers of specimens with three- (or more)needle dwarf shoots than populations at lower altitudes (Fig. 3). The frequency of specimens containing abnormal dwarf shoots and the frequency of abnormal dwarf shoots in the population with position in altitudinal range correlates positively and strongly statistically signifi- 
cantly (Pearson's $r=0.8602$ and $r=0.9205$, respectively). The frequency of specimens containing abnormal dwarf shoots and the frequency of abnormal dwarf shoots in the population are each strongly correlated with the recalculated altitudes of the sampled populations $(r=0.7538$ and $\mathrm{r}=$ 0.8288 respectively). The relationships are non-linear (polynomial), and for the lower altitudes are slightly negatively correlated, whereas for the mid and upper portions of the altitudinal range the correlations were strongly positive (Figs 5A and B).

\section{Variation in time}

The population of Pinus uncinata from Vall de Nuria in the East Pyrenees was examined in 1999 and 2001 (Table 1, samples no 21 and 22). The frequency of three-needle dwarf shoots varied between years, but was significantly higher compared to the other studied populations of the species (Table 3).

\section{Morphological characteristics of needles from more than two-needle dwarf shoots}

Needle length

As compared to two-needle dwarf shoots, the length of needles from the three-needle dwarf shoots are more variable (variation coefficient 12-21\%). The needles from threeneedle dwarf shoots are generally somewhat shorter. The average difference between the lengths of the needles from two- and three-needled dwarf shoots is at about 1-2 mm and is statistically insignificant (Table 4). Also needles from four-needle dwarf shoots are shorter than those of two-needle dwarf shoots, but the number of such dwarf shoots was to small to be compared statistically.
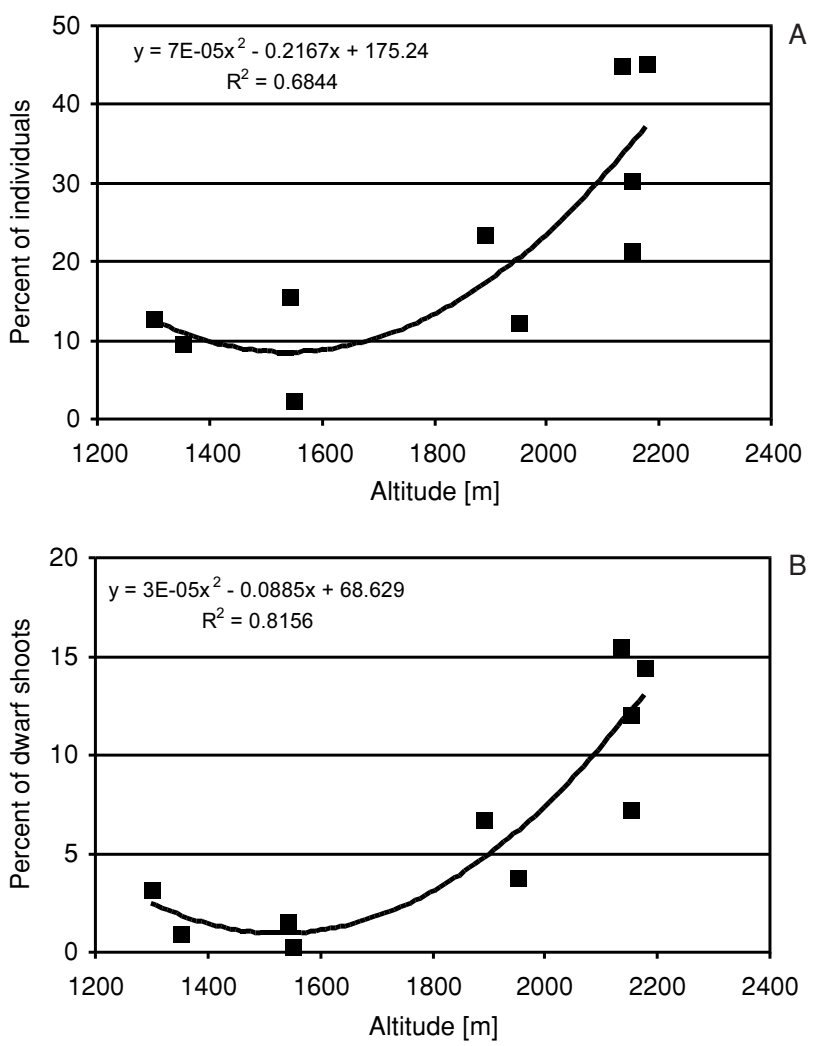

Fig. 5. Relationships of the frequency of Pinus uncinata individuals with three-needle dwarf shoots (A) and three needle dwarf shoots (B) in particular populations and its altitudinal origin.
TABLE 4. Length of needles from two- and three-needle dwarf shoots of Pinus mugo and Pinus uncinata.

\begin{tabular}{|c|c|c|c|c|c|c|}
\hline \multirow{3}{*}{ Species } & \multirow{3}{*}{$\begin{array}{l}\text { Popu- } \\
\text { lation }\end{array}$} & \multicolumn{3}{|c|}{ Two-needle dwarf shoots } & \multirow{3}{*}{$\mathrm{t}$} & \multirow{3}{*}{$\mathrm{p}$} \\
\hline & & \multicolumn{3}{|c|}{ Three-nedle dwarf shoots } & & \\
\hline & & $\mathrm{X}[\mathrm{mm}]$ & $\delta$ & $\mathrm{V}$ & & \\
\hline \multirow{4}{*}{$\begin{array}{l}\text { Pinus } \\
\text { mugo }\end{array}$} & \multirow{2}{*}{10} & 54.3 & 6.8138 & 12.54 & \multirow{2}{*}{0.9414} & \multirow{2}{*}{0.3567} \\
\hline & & 51.3 & 8.1172 & 15.81 & & \\
\hline & \multirow{2}{*}{15} & 48.7 & 6.1733 & 12.67 & \multirow{2}{*}{0.5017} & \multirow{2}{*}{0.6205} \\
\hline & & 47.4 & 6.8773 & 14.51 & & \\
\hline \multirow{10}{*}{$\begin{array}{l}\text { Pinus } \\
\text { uncinata }\end{array}$} & \multirow{2}{*}{20} & 76.7 & 12.9861 & 16.93 & \multirow{2}{*}{0.3437} & \multirow{2}{*}{0.7356} \\
\hline & & 74.4 & 13.8910 & 18.68 & & \\
\hline & \multirow{2}{*}{21} & 57.9 & 6.8178 & 11.78 & \multirow{2}{*}{0.6015} & \multirow{2}{*}{0.5537} \\
\hline & & 56.2 & 6.4983 & 11.57 & & \\
\hline & \multirow{2}{*}{22} & 62.7 & 7.8 .091 & 12.46 & \multirow{2}{*}{0.5667} & \multirow{2}{*}{0.5746} \\
\hline & & 61.2 & 7.4494 & 12.17 & & \\
\hline & \multirow{2}{*}{24} & 61.4 & 13.4710 & 21.96 & \multirow{2}{*}{0.0324} & \multirow{2}{*}{0.9752} \\
\hline & & 61.0 & 12.9637 & 21.26 & & \\
\hline & \multirow{2}{*}{25} & 63.5 & 9.2336 & 14.55 & \multirow{2}{*}{0.5574} & \multirow{2}{*}{0.586} \\
\hline & & 61.0 & 7.0702 & 11.59 & & \\
\hline
\end{tabular}

$\mathrm{X}$ - average length (arithmetic mean)

$\delta$ - standard deviation

$\mathrm{V}$ - variation coefficient

$\mathrm{t}$ - Student's t-test value

$\mathrm{p}$ - probability level

Needle cross-section

Morphological and anatomical differences between needles from two- and three-needle dwarf shoots are observed in the shape of the cross-section. The needles from two-needle dwarf shoots are semicircular in cross-section, whereas the needles from three-needle dwarf shoots are nearly triangular.

Each of the needles within the four-needle dwarf shoots is of the same length or the two marginal needles are significantly longer than the central ones. In the first type of four-needle dwarf shoot, needles are nearly triangular in cross-section, so that the four needles together form a circle (Fig. 6A). In the second type (with needles of different length), the larger marginal needles are crescent-shaped in cross-section, whereas the shorter central needles are semicircular to triangular (Fig. 6B).

The needles from five-needle dwarf shoots vary considerably in length, thickness and shape of cross-section even within the same dwarf shoot. The marginal needles are usually longer and semicircular, whereas the central needles are significantly shorter, more slender and have various shapes of cross-sections: from triangular to quadrangular or somewhat ovate (Figs 6C and 6D). The needles from the only six-needle dwarf shoot (found on Pinus uncinata in Central Massif) also vary in length, thickness and shape of cross-section (Fig. 6E).

\section{DISCUSSION AND CONCLUSIONS}

The analysis of the frequency of dwarf shoots with more than two needles among the taxa studied shows that they 


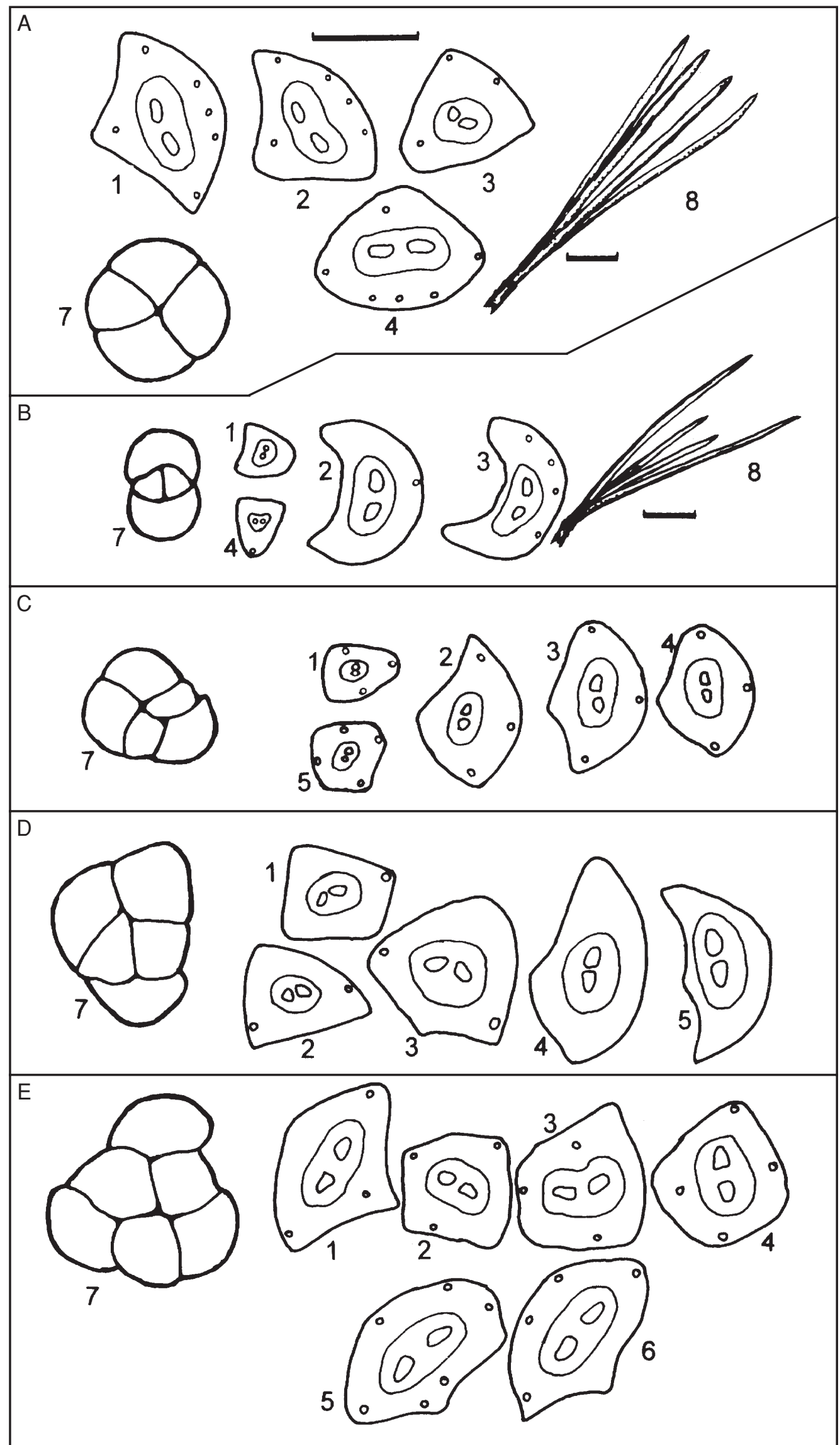

Fig. 6. The shape of cross-section of the needles and its composition on the dwarf shoot: A - 4-needle dwarf shoot with the needles of the same length (Pinus uncinata from population No 29); B - 4-needle dwarf shoot with needles of various length (Pinus uncinata from population No 27); C - 5-needle dwarf shoot (Pinus mugo from population No 1); D - 5-needle dwarf shoot (Pinus uncinata from population No 20); E - 6-needle dwarf shoot (Pinus uncinata from population No 29); 1-6 needles; 7 - scheme of the needles composition on dwarf shoot; 8 - scheme of dwarf shoot. 
appear in Pinus mugo and P. uncinata. All the other taxa either do not have three-needle dwarf shoots at all, as in the case of $P$. nigra (1 population) and $P$. uliginosa (2 populations), or the frequency of three-needle dwarf shoots is to low to be detected, as in $P$. sylvestris ( 1 specimen in 6 populations) and $P$. pinaster (1 specimen in 1 population). However, even single specimens with three-needle dwarf shoots confirm literature records of the occurrence of abnormal shoot on normally two-needle pine species in Europe (Penzig 1922; Klaus and Zetter 1978).

It can be also concluded, that the three- to six-needle dwarf shoots are formed most frequently on specimens of the Pinus mugo complex, including $P$. mugo, $P$. uncinata and $P$. uliginosa (Christensen 1987a). Abnormal dwarf shoots have been found on specimens of $P$. mugo and $P$. uncinata, but not on $P$. uliginosa. Perhaps this is related to the low altitude of the studied populations of $P$. uliginosa (about 200 and $700 \mathrm{~m}$ ), as compared with the studied populations of $P$. mugo and P. uncinata (see Table 1). The taxonomic relationship to $P$. sylvestris may also possibly explain the lack of abnormal numbers of needles in dwarf shoots on $P$. uliginosa. This taxon shows intermediate characteristics between $P$. mugo and $P$. sylvestris (see for example Staszkiewicz and Tyszkiewicz 1972; Bobowicz 1990; Staszkiewicz 1994; Siedlewska and Prus-Głowacki 1995; Prus-Głowacki et al. 1998; Lewandowski et al. 2000).

The majority of specimens with abnormal dwarf shoots on Pinus mugo and P. uncinata are found at the upper limits of the ranges of these species in the mountains, which is in consistent with observations of Christensen from herbaria review (1987b). High frequencies of abnormal dwarf shoots are also found in the northernmost populations of the $P$. mugo complex in the Carpathians and the Sudeten Mts. However, both populations of $P$. uliginosa are exceptions to this rule, although they are the northernmost among the studied populations of the $P$. mugo complex.

The three-needle specimens of Pinus mugo have not been reported from the Dynarian Alps and from the southern part of Balkan Peninsula (Christensen 1987b). They have not been found in the Vitosha Mts. in the present study. Our material from Balkan Peninsula is insufficient to state that specimens with abnormal numbers of needles in dwarf shoots are absent in Balkan portion of the species range. It should be noted, however, that the frequency of specimens bearing three-needle dwarf shoots is significantly lower in the south-eastern portion of the range of $P$. mugo than in the northern portion. In the Abruzzi Mts. specimens with three-needle dwarf shoots are also not so frequent as in the Carpathians - Sudeten range (Table 3).

The high frequencies of abnormal dwarf shoots have repeated in samples collected over 2-3 years in the same populations. This may indicate that formation of three-needle dwarf shoots is genetically conditioned and perhaps characteristic for local populations of Pinus mugo and/or $P$. uncinata. The differences among frequencies of abnormal dwarf shoots in particular years in the populations analyzed may be due to collecting samples from different individuals. Also the impact of environmental conditions should be taken into consideration, but this issue should be the subject of more detailed research on permanent plots and marked individuals in the future.

The three-needle dwarf shoots on Pinus sylvestris seedlings result from regeneration after mechanical damage
(Szymański 1958; Giertych 1968). This should be checked experimentally in the case of $P$. mugo and $P$. uncinata. All individuals of these species from which the material for the present study was collected had no visible injuries or symptoms of disease.

\section{ACKNOWLEDGEMENTS}

The present study was possible thanks to the cooperation of Institute of the Dendrology with the Kholodny's Institute of Botany in Kiev (sponsored by the Polish Committee for Scientific Research and National Academy of Sciences of Ukraine) and the Institute of Botany in Barcelona (sponsored by the Polish Academy of Sciences and the Consejo Superior de Investigaciones Cientificas). We thank Dr. J.M. Montserrat from Institute of Botany in Barcelona and Dr. J.P. Didukh in from Institute of Botany in Kiev for assistance in making the material collection possible and $\mathrm{V}$. Rodina for assistance in the field in the Ukrainian Carpathians. We are grateful to M. Tjoelker who helped to improve the manuscript. The study was sponsored in part by the Polish Committee for Scientific Research, grant No 6P04G 06016.

\section{LITERATURE CITED}

AMARAL FranCO J. 1984. Pinus L. In: S. Castroviejo, M. Laínz, G. López Gonzáles, P. Montserrat, F. Muñoz Garméndia, J. Paiva, L. Villar (eds). Flora iberica, vol. 1: 168-174. Real Jardín Botánico and Consejo Superiod de Investigactiones Cientificas, Madrid.

BOBOWICZ M.A. 1990. Hybrids of Pinus mugo Turra $\times$ Pinus sylvestris L. from the Bór na Czerwonem peatbog in Nowy Targ Valley. Edit. Of A. Mickiewicz University, Poaznań. (In Polish with English summary).

BONO G., BARBERO M., POIRON L. 1967. Groupements de Pinus mugo Turra (Pinus mughus Scop.) dans les Alpes Maritimes et Ligures. Allionia 13: 55-80.

BORATYŃSKI A. 1993. Systematics and geographical distribution. In: S. Białobok, A. Boratyński, W. Bugała (eds). Biology of Scots pine. Instytut Dendrologii PAN, Kórnik, Sorus, Poznań. pp: 45-69. (In Polish with English summary).

BORATYŃSKI A. 1994. Protected and deserving protection trees and shrubs from the Polish part of Sudeten Mts. with its prealps. 7. Pinus mugo Turra and Pinus uliginosa Neumann. Arbor. Kórnickie 39: 63-85. (In Polish with English summary).

BORATYŃSKI A., DIDUKH JA. P., TOMASZEWSKI D. 2000. Cone cluster form of Pinus uncinata Ramond (Pinaceae) Roczn. Dendr. 48: 183-185.

BORATYŃSKI A., DIDUKH Y., TASENKEVICH L. 2003a. Pinus mugo in the Ukrainian Carpathians. Dendrobiology 50 (in print).

BORATYŃSKI A., KOSIŃSKI P., BORATYŃSKA K., TOMASZEWSKI D. 2003b. Dendroflora of Andorra. Unpublished manuscript. Institute of Dendrology, Kórnik. 40 pp.

CARILLO I ORTUÑO E., NINOT I SURGAÑES J.M. 1992. Flora i vegetació de les Valls d'Espot i de Boí. Institut d'Estudis Catalans, Arxius de la Secció de Ciècies 99, 1-2. Barcelona.

CHOPIK V.I. 1976. The high mountain flora of the Ukrainian Carpathians. Naukova Dumka, Kiev. 269 pp. (In Ukrainian).

CHRISTENSEN K.I. 1987a. Taxonomic revision of the Pinus mugo comples and P.xrhaertica $(P$. mugo $\times$ sylvestris) (Pinaceae). Nordic J. Bot. 7: 383-408.

CHRISTENSEN K.I. 1987b. Atypical cone and leaf character states in Pinus mugo Turra, P. sylvestris L., and P. xrhaetica Brügger (Pinaceae). Gleditschia 15 (1): 1-5. 
DEBAZAC E.F. 1962. Note sur le bourgeon interfasciculaire et les aiguilles surnuméraires chez les Pins. Bull. Soc. Bot. France 109: 1-5.

FENAROLI L., GAMBI G. 1976. Alberi. Museo Tridentino di Scienze Naturali. Trento. 717 pp.

GIERTYCH M. 1968. The process of crown restoration following debudding of Pinus silvestris. III Symposium on Plant Growth Regulators, Toruń 11-14.09.1968.

GYÖRFFY I. 1932. Über Abnormitäten einiger Conifere-Blätter. Ber. Deutsche Bot. Gesellsch., S. L. 5: 227-228.

Jähring M. 1962. Beiträge zur Nadelanatomie und Taxonomie der Gattung Pinus L. Willdenowia 3 (2): 329-366.

KLAUS W., ZETTER R. 1978. Lokalrassen und dreinadelige Kurztriebe bei der Krummholz-Kiefer (Pinus mugo) auf der Rax-Alpen (Niederösterreich). Plant Syst. Evol. 130: 161-162.

KRÓL A. 1983/1984. Occurrence of three-needle dwarf shoots in Scots pine (Pinus silvestris L.). Roczn. Dendr. 35: 139-140. (In Polish).

LEWANDOWSKI A., BORATYŃSKI A., MEJNARTOWICZ L. 2000. Allozyme investigations on the genetic differentiation between closely related pines - Pinus sylvestris, $P$. mugo, $P$. uncinata, and P. uliginosa (Pinaceae). Plant Syst. Evol. 221: 15-24.

LITTLE E. Jr., CRITCHFIELD W.B. 1969. Subdivision of the Genus Pinus (Pines). U.S. Dept. Agricult., Forest Service, Misc. Publ. 1144. Washington.

MEUSEL H., JÄGER E., WEINERT E. 1965. Vergleichende Chorologie der zantraleuropäischen Flora. Vol. 1.1. G. Fischer, Jena, 583 pp.

MINGHETTI P. 1997. Contributo alla conoscenza di Pinus mugo agg. in Trentino (Italia): un approccio biometrico. Webbia 52 (1): 67-85.

PAWŁOWSKI B. 1956. Flora Tatrorum. Plantae vasculares. Tomus I. Academia Scientiarum Polona, Varsoviae. 672 pp. (In Polish).

PRUS-GŁOWACKI W., BUJAS E., RATYŃSKA H. 1998. Taxonomic position of Pinus uliginosa Neumann as related to other taxa of Pinus mugo complex. Acta Soc. Bot. Pol. 67 (3$-4): 269-274$

PRZYBYLSKI T. 1970. Morphology. In: S. Białobok (ed.). Scots pine, Pinus sylvestris L. Nasze Drzewa Leśne, 1: 86-120. (In Polish with English summary)
RETTICH K. 1932. Zapfensucht bei Pinus silvestris. Mitt. Deutsch. Dendr. Gesellsch. 44: 410.

SCHNEIDER W. 1913. Vergleichend-morphologische Untersuchungen über die Kurztriebe einiger Arten von Pinus. Flora 105: 385-446.

SIEDLEWSKA A., PRUS-GŁOWACKI W. 1995. Genetic structure and taxonomic position of Pinus uliginosa Neumann population from Wielkie Torfowisko Batorowskie in Stołowe Mts. (Locus classicus). Acta Soc. Bot. Pol. 64 (1): 51-58.

SKAWIŃSKI P. 1975. The three-needle mountain pine Pinus montana Mill. In the Tatra Mts. Studia Ośr. Dok. Fizjogr. 4: 221-223. (In Polish with English summary).

STASZKIEWICZ J. 1994. Variability of Pinus mugo $\times$ P. sylvestris (Pinaceae) hybrid swarm in the Tisovnica nature reserve (Slovakia). Polish Botanical Studies, 5: 33-41.

STASZKIEWICZ J., TYSZKIEWICZ M. 1972. Variability of natural hybrids of Pinus sylvestris L. $\times$ Pinus mugo Turra $(=P$. rotundata Link) in South-West Poland and in the selected stands in Bohemia and Moravia Fragmenta Floristica et Geobotanica 18 (2): 173-191. (In Polish with English summary).

STOYANOV N. 1963. Gymnospermae. In: Flora Reipublicae Popularis Bulgaricae, 1: 145-178. Sofia. (In Bulgarian).

SZYMAŃSKI S. 1958. Characteristics of regeneration in the Scots pine seedlings. Rocz. Dendr. 12: 413-420. (In Polish).

ŚRODON A. 1948. The upper forest line in the Czarnohora and Czivczin Mts. Rozprawy Wydziału Matematyczno-Przyrodniczego PAU, 72. Kraków (In Polish).

UNDERWOOD A.J. 1997. Experiments in ecology: their logical design and interpretation using analysis of variance. Cambridge Univeristy Press. 504 pp.

VIGO I BONADA J. 1983. El poblement vegetal de la Vall de Ribes. Acta Botanica Barcinonensia 35: 1-793.

VILLAR L. 1980. Catálogo florístico del Pirineo Occidental Español. Publicaciones de Centro Pirenaico de Biologia Experimental, 11: 1-422. Jaca (Huesca).

ZAR J.H. 1999. Biostatistical Analysis. Fourth edition, PrenticeHall, New Jersey.

\section{WYSTĘPOWANIE KRÓTKOPĘDÓW PINUS MUGO I P. UNCINATA O NIETYPOWEJ LICZBIE IGIEŁ}

\section{STRESZCZENIE}

Badano częstotliwość występowania nietypowych, trzyigłowych (lub więcej) krótkopędów na naturalnych stanowiskach południowo- i środkowoeuropejskich gatunków sosen dwuigłowych. Nie znaleziono okazów z nietypowymi krótkopędami w analizowanej populacji Pinus nigra Arnold subsp. salzmannii (Dunal) Franco z Półwyspu Iberyjskiego, ani w dwóch populacjach $P$. uliginosa Neumann $(=P$. rotundata Link) z Sudetów i ich przedpola w środkowej Europie. Pojedyncze osobniki z trzyigłowymi krótkopędami znaleziono w jednej analizowanej pod tym względem populacji $P$. pinaster Aiton z Półwyspu Iberyjskiego oraz sześciu populacjach $P$. sylvestris L. z Półwyspu Iberyjskiego i środkowej Europy. Nietypowe brachyblasty, najczęściej z trzema, ale także z czterema, pięciu lub sześciu igłami, znaleziono na wielu okazach w 24 na 25 badanych pod tym względem populacjach $P$. mugo Turra i $P$. uncinata Ramond. Przeciętny udział osobników z przynajmniej jednym trzyigłowym krótkopędem na jeden długopęd wynosił $24 \%$ w grupie 694 badanych okazów $P$. mugo i $20 \%$ w grupie 376 okazów $P$. uncinata. Analizowane populacje różniły się istotnie pod względem częstotliwości występowania osobników z nietypowymi krótkopędami. Największym udziałem takich osobników odznaczały się populacje pochodzące z górnych partii zasięgów gatunków. Częstość występowania nietypowych krótkopędów utrzymywała się na wysokim poziomie w kolejnych 2-3 latach obserwacji w jednej badanej pod tym względem populacji $P$. uncinata i w 2 populacjach $P$. mugo. Igły z trzyigłowych krótkopędów były przeciętnie krótsze (statystycznie nieistotnie) od igieł z krótkopędów typowych, niezależnie od gatunku.

SŁOWA KLUCZOWE: Pinus mugo, Pinus uncinata, zróżnicowanie morfologiczne, zmienność morfologiczna, nietypowe krótkopędy, brachyblasty, Europa. 